\title{
Understanding Information Technology: What Do Graduates from Business-Oriented IS Curricula Need to Know?
}

\author{
John Beachboard and Kevin R. Parker \\ Idaho State University, Pocatello, ID, USA
}

beach@isu.edu ParkerKR@isu.edu

\begin{abstract}
This paper describes the results of a study designed to assess the practical relevance of learning objectives for a course that corresponds to the IS 2002.4 recommended guidelines for an information technology hardware and systems software course. This study represents the first step in identifying the baseline technical knowledge that IS majors should possess upon entering practice. The survey reveals a general consensus among survey participants, consisting of experienced IT academics and practitioners, that learning objectives associated with systems thinking, systems administration functions, and information assurance practices are useful. However, the survey revealed that study participants had notably different perceptions concerning the value of learning objectives associated with achieving a deeper understanding of technical concepts concerning the design and functioning of hardware and systems software. The identification of these systematically differing perceptions among IT professionals is provocative and warrants further investigation.
\end{abstract}

Keywords: IS2002.4 model curriculum, hardware concepts, operating system concepts, technical knowledge, MIS/CIS/IS curriculum

\section{Introduction}

The IS 2002 Model Curriculum and Guidelines for Undergraduate Degree Programs in Information Systems, a joint effort of the ACM, AIS, and AITP societies, represents the most recent product of an effort to assist universities in developing degree programs that will produce "graduates equipped to function in entry-level information systems positions with a strong basis for continued career growth" (Gorgone, Davis, Valacich, Topi, Feinstein \& Longenecker, 2002, p. vi). While primarily an effort intended to provide curriculum guidance for IS programs within AACSB-accredited colleges, the model curriculum addresses curriculum content issues that should also be of interest to IS curriculum designers from outside of the United States. The model curriculum report indicates that the typical business school student graduating with an MIS or CIS emphasis may lack the technical skills today's IS employers are seeking. Therefore, the revised model curriculum responds to industry requests for "increased emphasis in technical orien-

Material published as part of this journal, either on-line or in print, is copyrighted by Informing Science. Permission to make digital or paper copy of part or all of these works for personal or classroom use is granted without fee provided that the copies are not made or distributed for profit or commercial advantage AND that copies 1) bear this notice in full and 2) give the full citation on the first page. It is permissible to abstract these works so long as credit is given. To copy in all other cases or to republish or to post on a server or to redistribute to lists requires specific permission from the publisher at Publisher@InformingScience.org tation..." (2002, p. vi).

While IS 2002 addresses the entire IS curriculum, this paper focuses specifically on the issue of defining what constitutes an appropriate breadth and depth of coverage for courses designed to satisfy the learning objectives specified for the IS 2002.4 - In- 
formation Technology Hardware and Systems Software course. The inclusion of the IS2002.4 course within the model curriculum is to enable students "to explain in systems terms the fundamental characteristics and components of computer and telecommunications hardware, and system software, and demonstrate how these components interact" (Gorgone et al., 2002, p. 44). However, questions remain concerning the selection of specific course content required to achieve learning goals specified in the curriculum report.

This study is predicated on agreement with the IS 2002 report's assumption that there are benefits to a reference model curriculum built around "a fundamental body of computing and information systems knowledge" (Gorgone et al., 2002, p. v). Given that some depth must be sacrificed to achieve the desired breadth of coverage identified in the model curriculum, the authors believe that the IS community should more fully specify the baseline technical concepts and skills that graduating IS students should possess. The intent of this study was to initiate the process of determining a baseline or "least common denominator" set of IT-related knowledge and skills that all graduating business-oriented IS students should possess irrespective of their specialized interests. (We use the term "business-oriented IS" to refer to information systems programs offered in AACSB-accredited colleges of business, as opposed to IS-related offerings from other colleges that are not subject to the same accreditation restrictions.)

\section{Issue Motivating Development of Pilot Study}

The IS 2002.4 course specification is intended to provide the "hardware/software technology background to enable systems development personnel to understand tradeoffs in computer architecture for effective use in a business environment.... system architecture for networked computing systems and operating systems will be covered" (Gorgone et al., 2002, p. 26). Table 1 lists the learning unit goals specified for this course.

Table 1. IS 2002.4 - Information Technology Hardware and System Software (Gorgone et al., 2002, p. 44)

\begin{tabular}{|c|c|}
\hline \begin{tabular}{l|} 
Learning \\
Unit \\
Number
\end{tabular} & Learning Unit Goal \\
\hline 62 & $\begin{array}{l}\text { To explain in systems terms the fundamental characteristics and components of } \\
\text { computer and telecommunications hardware, and system software, and demon- } \\
\text { strate how these components interact }\end{array}$ \\
\hline 63 & To provide an overview of peripheral devices and their function \\
\hline 64 & To introduce the concepts of computer hardware architectures \\
\hline 65 & To introduce the concepts of system software components and interactions \\
\hline 67 & $\begin{array}{l}\text { To introduce the major concepts in operating systems, including process defini- } \\
\text { tion, concurrent processing, memory management, scheduling, interrupt process- } \\
\text { ing, security, and file systems }\end{array}$ \\
\hline 68 & $\begin{array}{l}\text { To introduce a variety of operating environments (traditional, GUI, multimedia) } \\
\text { and resource requirements }\end{array}$ \\
\hline 69 & To discuss, explain, and install multimedia facilities \\
\hline 70 & To introduce the requirements for interoperability and systems integration \\
\hline 71 & To install, configure, and operate a multi-user operating system \\
\hline
\end{tabular}


These unit goals present course designers with a significant challenge. The sheer amount of conceptual information implicit in these objectives is more than can be presented within a single three-credit-hour course. Units 62 through 64 and 70 are consistent with the objectives of a typical three-credit-hour course in systems architecture required by many computer science programs. Units 65 through 68 reflect the topics taught in a separate three-credit-hour course on operating systems. See, for example, Tanenbaum's $(1999,2001)$ 600-plus page text on computer organization and 900-plus page text on modern operating systems. Admittedly, there must be an expectation that the 2002.4 course will cover a subset of the content offered in the corresponding six credit hours of computer science courses, yet selecting which concepts to emphasize and which to omit can prove problematic. The danger is that presenting too much material in a single course will cause student comprehension and retention to suffer. Consequently, instructors face the challenge of determining how much of the traditional computer science content can be reasonably omitted.

In addition to the volume of conceptual information to be presented, learning unit 71 establishes the objective for students to be able to install, configure and operate a multi-user operating system. Although this does not necessarily imply that students are to become certified Windows or Unix systems administrators, the inclusion of this objective within the IS 2002.4 course as outlined can be viewed as trivializing the level of knowledge required to understand and perform systems administration tasks associated with the configuration and operation of multi-user operating systems. The need to provide meaningful laboratory exercises requires additional time and is also affected by staffing and facility constraints.

In short, the theoretical and practical course goals for IS 2002.4 are broadly defined and appear to exceed the amount of content that can be reasonably presented in a three-semester-hour course. Yet, if the interpretation of the learning goals is narrowed too much there is a risk of undermining the intent of the revised curriculum to provide students with the desired level of technical competency. Individual instructors can choose to emphasize what they believe to be the most important, as has been done in designing our existing course offering. However, the broader IS community will benefit if it can reach a common understanding of baseline technical knowledge that should be required of graduates emerging from university programs.

\section{Implementation of the Study}

The purpose of the pilot study was to investigate practitioner and academic perceptions regarding the usefulness of a detailed list of learning objectives related to data representation, systems architecture and operating systems.

The authors reviewed literature addressing the identification of IT skill and knowledge requirements (Lee, Trauth \& Farwell, 1995; Lee, Yen, Havelka \& Koh, 2001; Trauth, Farwell \& Lee, 1993; Yen, Chen, Koh \& Lee, 2005) and identified only one study that approximated the level of detail concerning technical knowledge requirements examined in our study: the information technology career cluster initiative sponsored by the US Department of Education and the National School to Work Office. These studies were of limited use as they address knowledge and learning objectives at the curriculum rather than course level, and the survey items tend to be skillsoriented. For example, the surveys typically include items such as the ability to "support hardware" and "support information access and security" without specifying the knowledge required to effectively perform these tasks. Additionally, the number of respondents participating in these studies was relatively small, ranging from 14 to 39 for the various categories of skills assessed in the EDC study (2002), 77 participants in the Lee, et al. 1995 study, and 85 participants in the Lee, et al. 2001 study. Given a lack of literature specifically addressing technical knowledge requirements at the desired level of detail, the researchers decided that exploratory research was merited. 
This study was formulated based on a "strawman" set of learning objectives drawn from a course offering structured around Burd's (2001) text, but which also incorporated materials from additional sources. Learning objectives were selected to provide some technical depth to accompany the considerable breadth of topics addressed in the course. For example, one learning objective requires students to understand the use of Boolean operators in the construction of a simplified adder circuit. The intent of this objective is to provide students with an understanding of the physical and logical layers within a system design. The rationale for the course design and learning objectives from which this survey was prepared is presented more fully in Beachboard and Parker (2003).

The learning objectives were organized into seven general topic areas:

- Systems orientation to computer systems

- Overview of computer systems architecture and introduction to operating systems

- Data representation

- Motherboard and bus architectures

- Processor architectures

- Storage architectures

- System administration and security

In comparison to the content of textbooks intended for use in business-oriented architecture courses, our course offers more content related to general systems thinking, systems administration, and information assurance, and presents technical content in much less detail (Comer, 2005; Dale and Lewis, 2004; Englander, 2003; Burd, 2001). The survey results presented in Appendix A include the complete wording of the detailed learning objectives.

There were three separate rounds of pre-testing, two of which occurred online. The pre-testing included both academics and practitioners and resulted in several modifications to the survey instrument.

The authors posted a request for participation on the ISWorld Listserv. A second request was posted on behalf of the authors by the author of an online security newsletter sponsored by NWFusion. Over 500 participants started the survey, but only 217 usable responses were obtained.

\section{Demographic Profile of Respondents}

While the primary purpose of this research was to identify a general consensus within the IS community regarding the value of these objectives, each respondent was asked to indicate his or her professional relationship to the IS field. This segmented the respondents into one of five categories: IT practitioner, IT manager, IT educator, both an IT educator and IT practitioner, or an educator or practitioner of another field. Table 2 identifies the number and percentage of respondents in each category. 
Table 2. Professional Relationship to the IS Field

\begin{tabular}{|c|c|c|}
\hline Group & Respondents & Percentage \\
\hline I primarily work or teach in a field other than IS/IT & 8 & $3.69 \%$ \\
\hline $\begin{array}{l}\text { I primarily consider myself to be a managerially oriented } \\
\text { IS/IT practitioner }\end{array}$ & 95 & $43.78 \%$ \\
\hline $\begin{array}{l}\text { I primarily consider myself to be a technically oriented } \\
\text { IS/IT practitioner }\end{array}$ & 47 & $21.66 \%$ \\
\hline $\begin{array}{l}\text { I am significantly involved in both IS/IT practice and edu- } \\
\text { cation }\end{array}$ & 32 & $14.75 \%$ \\
\hline $\begin{array}{l}\text { I primarily consider myself to be an IS/IT academic or } \\
\text { educator }\end{array}$ & 35 & $16.13 \%$ \\
\hline Totals & 217 & $100 \%$ \\
\hline
\end{tabular}

Additional information was collected on the participants' primary occupational specialty. The development of these categories proved somewhat daunting given the large number of job titles employed in the IS field and the fact that many IS professionals have multiple duties. The breakdown of occupational specialties in Table 3 reflects categories used in the Education Development Center, Inc. (2002) study as well as input received through a query to the ISWorld Listserv. Even with the inclusion of 10 separate categories, over 10 percent of the respondents selected "other" or failed to answer this item.

Due to the relatively small numbers of respondents in each occupational category, the authors aggregated the data by collapsing the 10 categories into three: business applications development and support, infrastructure development and support, and information security. The business re-

Table 3. Occupational Specialties

\begin{tabular}{|l|r|r|}
\hline Area of Emphasis & Respondents & Percentage \\
\hline Internet / E-Commerce / Web Development & 8 & $3.69 \%$ \\
Business Requirements Analysis & 11 & $5.07 \%$ \\
Information Assurance / IT Security & 71 & $32.72 \%$ \\
Database Administration/Development & 8 & $3.69 \%$ \\
Applications Development \& Support & 12 & $5.53 \%$ \\
Enterprise Resource Planning (ERP) or Other Business & 9 & $4.15 \%$ \\
Application Specialist & & \\
Network / System Architecture Engineer / Architect / De- & 25 & $11.52 \%$ \\
signer & 29 & $13.36 \%$ \\
Network / Systems Administration / Systems Programmer & 8 & $3.69 \%$ \\
Software Engineer/Applications Architect & 10 & $4.61 \%$ \\
IT Support Services (Applications / Desktop) & 26 & $11.98 \%$ \\
Other or no entry & $\mathbf{2 1 7}$ & $\mathbf{1 0 0} \%$ \\
\hline Totals & & \\
\hline
\end{tabular}


quirements analysis, e-commerce, application development, ERP support, database administration and development and software engineering and applications architect were included in the applications development and support category. The system/network architects and administrators, and IT support services were categorized as infrastructure development and support. Given the variation in duties of individuals working within these occupational specialties, this re-categorization likely contains some error. Nonetheless, this categorization reveals interesting results when comparing relative perceptions among these aggregated occupational specialties (see Table 4).

Table 4. Occupational Specialties -- Aggregated

\begin{tabular}{|l|r|r|}
\hline Group & Respondents & Percentage \\
\hline Application Development/Support & 56 & $25.81 \%$ \\
Infrastructure Development/Support & 64 & $29.49 \%$ \\
Information Security & 71 & $32.72 \%$ \\
Other & 26 & $11.98 \%$ \\
Totals & $\mathbf{2 1 7}$ & $\mathbf{1 0 0} \%$ \\
\hline
\end{tabular}

\section{Summary and Analysis of Survey Results}

The survey identified 64 specific learning objectives grouped into seven general categories. Participants were asked to rate each learning objective on a 1 to 7 scale where a one (1) would indicate that the item has no importance or practical usefulness, a four (4) would indicate somewhat useful but not essential, and a seven (7) would indicate an essential item of knowledge that all IS professionals should fundamentally understand or be able to perform. Appendix A reports the number of responses, the mean, and the standard deviation for each substantive item in the survey. Given the length of the survey and the findings described below, individual item responses are not separately analyzed or discussed.

Table 5 reports the means and standard deviations of aggregated responses from all study participants for each of the seven knowledge categories ranked in order from the most-valued to leastvalued category. Using a substantive interpretation of the numeric values, 4.5 was identified as a cutoff for considering whether a topic was perceived as being of sufficient value to merit inclusion in future course designs. Recall that a rating of 4 would indicate the objective was perceived as being generally of interest but having little or no practical usefulness. Values below 4.5 (on a seven point scale) represent an extremely weak endorsement of the learning objective. Values ranging between 4.5 and 5.5 should be considered for inclusion but scrutinized closely if choices must be made relative to the selection of material associated with more highly valued learning objectives. Items receiving ratings higher than 5.5 appear to be of clear value and should be retained in the course.

The results presented in Table 5 are notable in several respects. Only two of the general categories of learning objectives were rated higher than the 5.5 cutoff: systems administration and security and systems orientation to computer systems. This finding is particularly interesting because these objectives represent content areas minimally addressed, if included at all, in the textbooks commonly associated with general system architecture courses (Burd, 2001; Comer, 2005; Dale \& Lewis, 2004; Englander, 2003). 
Table 5. Mean Response by Major Topic

\begin{tabular}{|c|l|r|r|r|}
\hline $\begin{array}{c}\text { Item } \\
\text { \# }\end{array}$ & $\begin{array}{l}\text { Item Descriptions. Learning Objectives Associated } \\
\text { With: }\end{array}$ & N & Mean & $\begin{array}{r}\text { Standard } \\
\text { Deviation }\end{array}$ \\
\hline SS & Systems Administration and Security & 209 & 6.29 & 0.61 \\
SO & Systems Orientation to Computer Systems & 213 & 5.79 & 0.62 \\
SA & Storage Architecture & 215 & 5.07 & 1.19 \\
OS & $\begin{array}{l}\text { Computer Systems Architecture Overview and Introduction } \\
\text { to Operating Systems }\end{array}$ & 207 & 4.90 & 1.03 \\
MA & Motherboard and Bus Architectures & 210 & 4.70 & 1.35 \\
DR & Data Representation & 213 & 4.42 & 1.21 \\
\hline PA & Processor Architecture & 210 & 4.40 & 1.35 \\
\hline
\end{tabular}

The next three topics, storage architecture, overview of computer architecture and operating systems, and motherboard and bus architectures, are notable in that they tend to include learning objectives more directly related to system use rather than providing a detailed technical understanding regarding how specific components work. For example, under the storage architecture category, understanding the performance implications of a system being forced to employ its virtual memory rated 5.49, while understanding the low-level formatting of hard disks was rated 4.47. This pattern is relatively consistent throughout the survey data, with the lowest values being assigned to concepts associated with a basic understanding of digital logic (4.07) and understanding the binary format of floating point numbers (4.03). These data are drawn from Appendix A.

The relative ranking of the more technically oriented learning objectives and those more directly associated with system use are not unexpected. However, given the emphasis placed on presenting this type of technical content in all of the referenced textbooks, it is somewhat surprising that these specific learning objectives were not more highly regarded.

Finally, Table 5 shows a relatively large difference in standard deviations for the two top-rated knowledge categories relative to those observed for the remaining five categories. The standard deviations noted for the storage architecture (1.19), motherboard architecture (1.35), data representation (1.21) and processor architecture (1.35) are roughly twice as large as the variance noted for systems administration and security $(0.61)$ and the systems orientation categories $(0.62)$. The relatively large standard deviations identified for the majority of subject categories raise a question as to whether there were systematic differences in the perceptions of survey participants.

Tables 6 and 7 report the mean aggregated responses within each of the seven knowledge categories. For each knowledge category, Table 6 includes the aggregated means for all respondents (Mean All) and for the four types of IS professional affiliation identified in the survey. Table 6 additionally includes an approximate $\mathrm{N}$ to indicate the number of respondents within each category. The $\mathrm{N}$ is approximate because some respondents failed to complete all of the survey items within each category. Table 7 is similar to Table 6 , but reports mean responses by occupational category. The Mean All category is repeated in Table 7 to allow for easier comparisons. 
Table 6. Mean Response by Topic and IS Profession

\begin{tabular}{|c|c|c|c|c|c|}
\hline Topic Category & $\begin{array}{l}\text { Mean } \\
\text { All }\end{array}$ & Academic & $\begin{array}{c}\text { Academic } \\
\text { \& Practitio- } \\
\text { ner }\end{array}$ & $\begin{array}{l}\text { Mgr } \\
\text { Practi- } \\
\text { tioner }\end{array}$ & $\begin{array}{l}\text { Technical } \\
\text { Practitioner }\end{array}$ \\
\hline Approximate $\mathrm{N}$ & 213 & 35 & 32 & 46 & 94 \\
\hline $\begin{array}{l}\text { System Administration } \\
\text { and Security }\end{array}$ & 6.29 & 6.09 & 6.09 & 6.36 & 6.38 \\
\hline $\begin{array}{l}\text { Systems Orientation to } \\
\text { Computer Systems }\end{array}$ & 5.79 & 5.69 & 5.76 & 5.74 & 5.84 \\
\hline Storage Architecture & 5.07 & 4.56 & 4.50 & 5.32 & 5.33 \\
\hline $\begin{array}{l}\text { Computer Systems Archi- } \\
\text { tecture Overview and } \\
\text { Introduction to Operating } \\
\text { Systems }\end{array}$ & 4.90 & 4.26 & 4.55 & 4.97 & 5.22 \\
\hline $\begin{array}{l}\text { Motherboard and Bus } \\
\text { Architectures }\end{array}$ & 4.70 & 4.07 & 4.10 & 4.97 & 4.97 \\
\hline Data Representation & 4.42 & 4.06 & 4.24 & 4.16 & 4.74 \\
\hline Processor Architecture & 4.40 & 4.04 & 3.95 & 4.42 & 4.66 \\
\hline
\end{tabular}

Table 7. Mean Response by Topic and IS Occupation

\begin{tabular}{|c|c|c|c|c|c|}
\hline Topic Category & $\begin{array}{c}\text { Mean } \\
\text { All }\end{array}$ & $\begin{array}{l}\text { Application } \\
\text { Dev/Spt }\end{array}$ & $\begin{array}{l}\text { Infrastructure } \\
\text { Dev/Spt }\end{array}$ & Security & Other \\
\hline Approximate $\mathrm{N}$ & 213 & 55 & 63 & 69 & 26 \\
\hline $\begin{array}{l}\text { System Administration } \\
\text { and Security }\end{array}$ & 6.29 & 6.14 & 6.42 & 6.30 & 6.28 \\
\hline $\begin{array}{l}\text { Systems Orientation to } \\
\text { Computer Systems }\end{array}$ & 5.79 & 5.81 & 5.78 & 5.77 & 5.81 \\
\hline Storage Architecture & 5.07 & 4.53 & 5.55 & 5.19 & 4.69 \\
\hline $\begin{array}{l}\text { Computer Systems Ar- } \\
\text { chitecture Overview and } \\
\text { Introduction to Operating } \\
\text { Systems }\end{array}$ & 4.90 & 4.50 & 5.34 & 4.98 & 4.49 \\
\hline $\begin{array}{l}\text { Motherboard and Bus } \\
\text { Architectures }\end{array}$ & 4.70 & 4.01 & 5.16 & 4.96 & 4.33 \\
\hline Data Representation & 4.42 & 4.10 & 4.74 & 4.44 & 4.29 \\
\hline Processor Architecture & 4.40 & 3.74 & 4.87 & 4.60 & 4.12 \\
\hline
\end{tabular}


A review of Tables 6 and 7 reveals differences among the mean responses for various categories of survey participants. While determining whether observed differences are statistically significant is relatively simple, interpreting the data and determining whether observed variations are substantively significant is somewhat problematic. For example, Table 6 reveals mean responses for the system administration and security category ranging from 6.09 to 6.38 among the professional affiliation categories. A simple one-way ANOVA test reveals a probability (P-value) of .039 , indicating that statistically significant differences among the category means do exist. However, relative to the mean differences observed among respondents for other topic categories, the observed means can be interpreted as indicating that substantive agreement exists among these respondent categories regarding this topic category. Given limitations associated with sample selection and size, the balance of this analysis focuses on a substantive, rather than statistical, interpretation of the data.

While the possibility of some systematic variance among survey respondent groups was anticipated, the size of those differences was not. The two most highly valued topic categories, systems orientation to computers and system administration and security, demonstrate relatively strong consensus among all respondent groups. Beyond those two categories, however, there were substantively significant differences in perceptions. In fact, raw score differences between the highest and lowest respondent groups often exceeded .5, with some greater than 1.0. Most notably, the views of those involved with infrastructure operations and support rated the processor architecture knowledge category at 4.87 , while those primarily involved with applications development rated that category at 3.74. The raw score difference of 1.13 equates to a .83 of the joint standard deviation, generally considered a large effect size in the social sciences (Cohen, 1988).

The various categories of respondents maintained roughly the same relative rating of knowledge categories. However, the differences among categories when viewed in light of the 4.5 cutoff would significantly impact the selection of material for inclusion in a proposed course. Category differences are even more pronounced when the professional categories and occupational categories are cross tabulated. An example of such a cross-tabulation comparison is provided in Appendix B

The reader is urged to review the tables to draw his or her own conclusions, but the survey results suggest the following:

- Practitioners tend to perceive more value in the majority of learning objectives than do academics and academic/practitioners.

- While the differences are not as pronounced, technical practitioners tend to more strongly value many of the learning objectives than do managerial practitioners or academics.

- Those involved primarily with infrastructure development and support perceive more value on the majority of items than do those involved in business application development and support.

- The perceptions of security professionals tend to fall between those of the applications developers and infrastructure administrators.

\section{Study Limitations}

As in any research, there are limitations in the design and execution of this study. The length of the survey instrument, in conjunction with some technical difficulties not apparent in the pre-test, inhibited completion of the survey by over half of the potential study participants. 
There are limitations stemming from how the survey participants were recruited. While ISWorld represents a good cross section of IS academics and reaches some practitioners, recruiting additional practitioners based on their subscribing to a security-related newsletter may result in a systematic sampling bias.

There were additional concerns regarding the interpretation of data. Respondents were explicitly asked to assess the value of these learning objectives as a baseline for all aspiring IT professionals. However, the substantive differences in perceptions suggest that either the knowledge requirements of various occupational specialties are too divergent to establish such a baseline, or that the desire to identify a common set of knowledge requirements to be shared by all IS professionals was not clearly understood by the survey respondents.

\section{Conclusion}

These initial findings warrant further investigation. The survey results clearly suggest that there may be substantive differences in the perceptions among various categories of IS professionals. Furthermore, the survey provides evidence that the fundamental structure of the IS2002.4 course, as reflected in available textbooks, could be significantly revamped to provide more practical relevance for IS students.

The relatively neutral attitudes expressed toward the value of technical concepts included in most CS and general IS architecture texts can be considered a significant finding. The time available to educate students is limited. Instructors cannot afford to invest that time and effort in providing instruction that provides little practical utility. Given the time constraints inherent in offering IS programs within AACSB-accredited colleges, the issue warrants further investigation.

A future study will utilize a qualitative, group-oriented approach in which selected study participants will be invited to compare their judgments with those of other IS professionals, to reflect upon and discuss perceived differences in opinion, and to determine whether greater consensus can be achieved. This study will make use of a nominal group technique based on an online version of the Delphi method (Edwards, 2003). The results of such a study will provide input to the construction of improved survey instruments.

While we agree with the specification of the IS2002 learning objectives related to developing an understanding of system hardware and software, and endorse the identified need to increase the technical orientation of IS graduates, our professional and academic experiences have alerted us to some concerns as to how well the objectives can be accommodated while constrained by the 10 -course curriculum limitation imposed by the accreditation standards for business schools (Gorgone, et al., 2002, pp. 7-8). The specified curriculum seems to require a significant tradeoff between the number of concepts that can be reasonably introduced and the level of detail with which these concepts can be presented.

One of the guiding principles of the model curriculum report is that the effort should "represent a consensus from the IS community" (Gorgone, et al., 2002, p. 5). This survey appears to reveal substantial disagreements among IS professionals concerning at least our operationalization of learning objectives associated with an IS 2002.4-compliant course. Further investigation is required to determine whether a consensus is possible with respect to establishing detailed learning objectives for an IT architecture and systems software course, or whether additional degrees of specialization should be introduced into the IS curricula within business-oriented programs. 


\section{References}

Beachboard, J. C. \& Parker, K. R. (2003). How much is enough? Teaching information technology in a business-oriented IS curriculum. Proceedings of the 2003 Americas Conference on Information Systems (AMCIS 2003), Tampa, FL, 3026-3031.

Burd, S. D. (2001). Systems architecture ( $3^{\text {rd }}$ ed.). Boston, MA: Course Technology.

Cohen, J. (1988). Statistical power for the behavioral sciences $\left(2^{\text {nd }}\right.$ ed.). Hillsdale, NJ: Lawrence Erlbaum and Associates.

Comer, D.E. (2005). Essentials of computer architecture. Upper Saddle River, NJ: Prentice-Hall.

Dale, N., \& Lewis J. (2004). Computer science illuminated ( $2^{\text {nd }}$ ed.). Sudbury, MA: Jones and Bartlett.

Education Development Center. (2002). Information technology career cluster initiative: Academic foundations and pathway standards validation studies. Retrieved December 5, 2004, from http://www2.edc.org/ewit/materials/ITCCIVSFinal.pdf

Edwards, J. K. (2003). Beginning on-line Delphi ethnographic research: The BOLDER method. The Qualitative Report, 8(2), 257-285.

Englander, E. (2003). The architecture of computer hardware and systems software: An information technology approach ( $3^{\text {rd }}$ ed.). New York, NY: John Wiley \& Sons.

Gorgone, J., Davis, G., Valacich, J., Topi, H., Feinstein, D. \& Longenecker, H. (2002). IS 2002: Model curriculum and guidelines for undergraduate programs in information systems. Retrieved December 3, 2003, from http://www.acm.org/education/is2002.pdf

Lee, D.M.S., Trauth, E.M., \& Farwell, D. (1995). Critical skills and knowledge requirements of IS professionals: A joint academic/industry investigation. MIS Quarterly, 19 (3), 313-340.

Lee, S., Yen, D., Havelka, D. \& Koh, S., (2001). Evolution of IS professionals' competency: An exploratory study. Journal of Computer Information Systems, 41 (4), 21-30.

Tanenbaum, A.S. (1999). Structured computer organization ( $4^{\text {th }}$ ed.). Upper Saddle River, NJ: PrenticeHall.

Tanenbaum, A.S. (2001). Modern operating systems ( $2^{\text {nd }}$ ed.). Upper Saddle River, NJ: Prentice-Hall.

Trauth, E. M., Farwell, D., \& Lee, D. M. S. (1993). The IS expectation gap: Industry expectations and academic preparation. MIS Quarterly, 13 (3), 293-307.

Yen, D. C., Chen, K., Koh, S. \& Lee, S. (2005),.An east-west comparison of IS professionals' performance and knowledge/skills: An empirical study of USA vs. Taiwan. Communications of the AIS, 15, 162182. 


\section{Appendix A}

\begin{tabular}{|l|l|l|l|r|}
\hline \multicolumn{5}{|l|}{ Systems Orientation to Computer Systems (SO) } \\
\hline $\begin{array}{l}\text { Item } \\
\text { \# }\end{array}$ & Item & N & Mean & $\begin{array}{r}\text { Standard } \\
\text { Deviation }\end{array}$ \\
\hline $\begin{array}{l}\text { SO- } \\
\mathbf{0 1}\end{array}$ & $\begin{array}{l}\text { Understand the fundamental concepts of systems and } \\
\text { dynamic systems: input, transformation, output, and } \\
\text { feedback }\end{array}$ & 217 & 5.87 & 1.28 \\
\hline $\begin{array}{l}\text { SO- } \\
\mathbf{0 2}\end{array}$ & $\begin{array}{l}\text { Understand that there can be multiple legitimate defini- } \\
\text { tions of systems depending on an individual's or or- } \\
\text { ganization's unique needs or perspectives }\end{array}$ & 217 & 5.47 & 1.13 \\
\hline $\begin{array}{l}\text { SO- } \\
\mathbf{0 3}\end{array}$ & $\begin{array}{l}\text { Understand complex systems in terms of a system of } \\
\text { systems or nested systems }\end{array}$ & 216 & 5.35 & 1.17 \\
\hline $\begin{array}{l}\text { SO- } \\
\mathbf{0 4}\end{array}$ & $\begin{array}{l}\text { Understand key elements comprising an information } \\
\text { system: users, information, processes, and technol- } \\
\text { ogy }\end{array}$ & 216 & 6.28 & 0.86 \\
\hline $\begin{array}{l}\text { SO- } \\
\mathbf{0 5}\end{array}$ & $\begin{array}{l}\text { Understand the distinction between a business appli- } \\
\text { cation and a business's IS/IT infrastructure }\end{array}$ & 217 & 5.93 & 1.07 \\
\hline $\begin{array}{l}\text { SO- } \\
\mathbf{0 6}\end{array}$ & $\begin{array}{l}\text { Understand that the IS/IT architecture consists of sys- } \\
\text { tems design choices and be able to distinguish be- } \\
\text { tween architecture design and the system as it is im- } \\
\text { plemented }\end{array}$ & 215 & 5.77 & 0.95 \\
\hline SO- & $\begin{array}{l}\text { Understand the relationship between technical knowl- } \\
\text { edge (as offered in the proposed course) and the abil- } \\
\text { ity to develop cost effective and operationally efficient } \\
\text { system architectures }\end{array}$ & 217 & 5.85 & 0.98 \\
\hline
\end{tabular}

\begin{tabular}{|c|c|c|c|c|}
\hline \multicolumn{5}{|c|}{$\begin{array}{l}\text { Computer Systems Architecture Overview and Introduction to Operating Sys- } \\
\text { tems (OS) }\end{array}$} \\
\hline $\begin{array}{l}\text { Item } \\
\#\end{array}$ & Item & $\mathbf{N}$ & Mean & $\begin{array}{l}\text { Standard } \\
\text { Deviation }\end{array}$ \\
\hline $\begin{array}{l}\text { OS- } \\
01\end{array}$ & $\begin{array}{l}\text { Ability to identify major components of a computer sys- } \\
\text { tem }\end{array}$ & 217 & 5.90 & 1.14 \\
\hline $\begin{array}{l}\text { OS- } \\
02\end{array}$ & $\begin{array}{l}\text { Understand the logic behind use of layered or modular } \\
\text { architecture in the design of information systems } \\
\text { hardware and software }\end{array}$ & 217 & 5.43 & 1.20 \\
\hline $\begin{array}{l}\text { OS- } \\
03\end{array}$ & $\begin{array}{l}\text { Understand the role of an operating system in manag- } \\
\text { ing system resources }\end{array}$ & 216 & 5.53 & 1.23 \\
\hline $\begin{array}{l}\text { OS- } \\
04\end{array}$ & $\begin{array}{l}\text { Understand the general concepts of timesharing, inter- } \\
\text { rupt processing, and rudimentary prioritization } \\
\text { schemes }\end{array}$ & 217 & 4.55 & 1.43 \\
\hline $\begin{array}{l}\text { OS- } \\
05\end{array}$ & $\begin{array}{l}\text { Understand the function and security implications of } \\
\text { OS memory management }\end{array}$ & 216 & 5.11 & 1.50 \\
\hline $\begin{array}{l}\text { OS- } \\
06\end{array}$ & Understand how an OS functions as a virtual machine & 215 & 4.67 & 1.48 \\
\hline $\begin{array}{l}\text { OS- } \\
07\end{array}$ & $\begin{array}{l}\text { Understand machine language, assembly language, } \\
\text { and higher-order language at a conceptual level }\end{array}$ & 217 & 4.15 & 1.49 \\
\hline $\begin{array}{l}\text { OS- } \\
08\end{array}$ & $\begin{array}{l}\text { Understand the function of high-level disk formatting } \\
\text { and relation between file allocation units/disk clusters } \\
\text { and the file allocation table }\end{array}$ & 216 & 4.19 & 1.56 \\
\hline
\end{tabular}




\begin{tabular}{|l|l|l|l|l|}
\hline \multicolumn{6}{|l|}{$\begin{array}{l}\text { Computer Systems Architecture Overview and Introduction to Operating Sys- } \\
\text { tems (OS) }\end{array}$} & N & Mean & $\begin{array}{l}\text { Standard } \\
\text { Deviation }\end{array}$ \\
\hline $\begin{array}{l}\text { Item } \\
\text { \# }\end{array}$ & Item & 215 & 4.60 & 1.46 \\
\hline $\begin{array}{l}\text { OS- } \\
\mathbf{0 9}\end{array}$ & $\begin{array}{l}\text { Understand disk partitioning and why a systems ad- } \\
\text { ministrator might choose to partition a hard drive }\end{array}$ & 216 & 4.40 & 1.56 \\
\hline $\begin{array}{l}\text { OS- } \\
\mathbf{1 0}\end{array}$ & $\begin{array}{l}\text { Understand why selection of disk cluster size can af- } \\
\text { fect disk storage efficiency and performance }\end{array}$ & 217 & 5.06 & 1.34 \\
\hline $\begin{array}{l}\text { OS- } \\
\mathbf{1 1}\end{array}$ & $\begin{array}{l}\text { Understand directory structures and how implementing } \\
\text { an inappropriate directory structure can impact system } \\
\text { performance }\end{array}$ & 216 & 5.12 & 1.51 \\
\hline $\begin{array}{l}\text { OS- } \\
\mathbf{1 2}\end{array}$ & $\begin{array}{l}\text { Understand the terms working directory, relative path, } \\
\text { and absolute path }\end{array}$ & 216 \\
\hline $\begin{array}{l}\text { OS- } \\
\mathbf{1 3}\end{array}$ & $\begin{array}{l}\text { Understand the purpose and fundamental operation of } \\
\text { a distributed file systems }\end{array}$ & 216 & 5.19 & 1.26 \\
\hline $\begin{array}{l}\text { OS- } \\
\mathbf{1 4}\end{array}$ & $\begin{array}{l}\text { Understand the distinction between static and dynamic } \\
\text { drive-space mapping and the function of network direc- } \\
\text { tory services }\end{array}$ & 214 & 4.83 & 1.36 \\
\hline
\end{tabular}

\section{Data Representation (DR)}

\begin{tabular}{|l|l|l|l|l|}
\hline $\begin{array}{l}\text { Item } \\
\#\end{array}$ & Item & N & Mean & $\begin{array}{l}\text { Standard } \\
\text { Deviation }\end{array}$ \\
\hline $\begin{array}{l}\text { DR- } \\
\mathbf{0 1}\end{array}$ & $\begin{array}{l}\text { Identify common primitive data types implemented in } \\
\text { modern processors Ability to manually perform binary- } \\
\text { to-decimal and decimal-to-binary number conversions }\end{array}$ & 217 & 4.53 & 1.45 \\
\hline $\begin{array}{l}\text { DR- } \\
\mathbf{0 2}\end{array}$ & $\begin{array}{l}\text { Understand the distinction between primitive and com- } \\
\text { plex data types and the distinction between primitive } \\
\text { data types and program language defined data types }\end{array}$ & 215 & 4.50 & 1.48 \\
\hline $\begin{array}{l}\text { DR- } \\
\mathbf{0 3}\end{array}$ & $\begin{array}{l}\text { Understand the tradeoffs implicit in selecting and de- } \\
\text { veloping a data representation scheme with regards to } \\
\text { its compactness, range, and accuracy }\end{array}$ & 217 & 4.87 & 1.41 \\
\hline $\begin{array}{l}\text { DR- } \\
\mathbf{0 4}\end{array}$ & $\begin{array}{l}\text { Understand the distinction between ASCll and Uni- } \\
\text { code character representation standards and be able } \\
\text { to explain limitations of ASCll character set relative to } \\
\text { Unicode }\end{array}$ & 216 & 4.30 & 1.50 \\
\hline $\begin{array}{l}\text { DR- } \\
\mathbf{0 5}\end{array}$ & $\begin{array}{l}\text { Understand the use of scientific notation in the devel- } \\
\text { opment of a primitive floating point data type }\end{array}$ & 216 & 4.03 & 1.54 \\
\hline DR- & $\begin{array}{l}\text { Understand the distinction between linked list and ar- } \\
\text { ray data structures in how the data is stored in memory } \\
\text { and the potential impact of using each on application } \\
\text { performance }\end{array}$ & 217 & 4.66 & 1.52 \\
\hline $\begin{array}{l}\text { DR- } \\
\mathbf{0 7}\end{array}$ & $\begin{array}{l}\text { Ability to manually perform binary-to-decimal and } \\
\text { decimal-to-binary number conversions }\end{array}$ & 217 & 4.03 & 1.88 \\
\hline
\end{tabular}




\begin{tabular}{|c|c|c|c|c|}
\hline \multicolumn{5}{|c|}{ Processor Architecture (PA) } \\
\hline $\begin{array}{l}\text { Item } \\
\#\end{array}$ & Item & $\mathbf{N}$ & Mean & $\begin{array}{l}\text { Standard } \\
\text { Deviation }\end{array}$ \\
\hline $\begin{array}{l}\text { PA- } \\
01\end{array}$ & $\begin{array}{l}\text { Ability to construct truth tables for basic Boolean } \\
\text { logic operators (AND, OR, XOR, NOT) }\end{array}$ & 4.94 & 1.61 & 4.94 \\
\hline $\begin{array}{l}\text { PA- } \\
02\end{array}$ & $\begin{array}{l}\text { Ability to manually perform binary addition, un- } \\
\text { derstand how binary addition works, and be able } \\
\text { to identify Boolean operators used in the design } \\
\text { of digital logic circuits to calculate primary and } \\
\text { carry bit positions in the binary addition operation }\end{array}$ & 4.28 & 1.75 & 4.28 \\
\hline $\begin{array}{l}\text { PA- } \\
03\end{array}$ & $\begin{array}{l}\text { Understand the relationship between the concept } \\
\text { of primitive data types, digital logic circuits used } \\
\text { in processor design, and computer word size }\end{array}$ & 4.07 & 1.61 & 4.07 \\
\hline $\begin{array}{l}\text { PA- } \\
04\end{array}$ & $\begin{array}{l}\text { Understand the application of Two's complement } \\
\text { notation in the design of digital logic circuits }\end{array}$ & 3.78 & 1.68 & 3.78 \\
\hline $\begin{array}{l}\text { PA- } \\
05\end{array}$ & $\begin{array}{l}\text { Ability to identify and explain the function of basic } \\
\text { elements comprising a microprocessor (registers, } \\
\text { arithmetic logic unit, and control unit) }\end{array}$ & 4.59 & 1.64 & 4.59 \\
\hline $\begin{array}{l}\text { PA- } \\
06\end{array}$ & $\begin{array}{l}\text { Understand processor clock speed and the im- } \\
\text { perfect relationship between processor clock } \\
\text { speed and processor performance }\end{array}$ & 4.62 & 1.53 & 4.62 \\
\hline $\begin{array}{l}\text { PA- } \\
07\end{array}$ & Understand fetch and execution cycles & 4.37 & 1.62 & 4.37 \\
\hline $\begin{array}{l}\text { PA- } \\
08\end{array}$ & $\begin{array}{l}\text { Understand the term "instruction set architecture" } \\
\text { and its relationship to machine language instruc- } \\
\text { tions }\end{array}$ & 4.21 & 1.62 & 4.21 \\
\hline $\begin{array}{l}\text { PA- } \\
09\end{array}$ & $\begin{array}{l}\text { Understand distinctions between CISC and RISC } \\
\text { processor architectures }\end{array}$ & 4.48 & 1.57 & 4.48 \\
\hline $\begin{array}{l}\text { PA- } \\
10\end{array}$ & $\begin{array}{l}\text { Understand basic design techniques used to in- } \\
\text { crease processor performance (pipelining, } \\
\text { branch-prediction, inclusion of specialized in- } \\
\text { struction circuitry such as MMX) }\end{array}$ & 4.55 & 1.62 & 4.55 \\
\hline
\end{tabular}




\begin{tabular}{|c|c|c|c|c|}
\hline \multicolumn{5}{|c|}{ Storage Architecture (SA) } \\
\hline $\begin{array}{l}\text { Item } \\
\text { \# }\end{array}$ & Item & $\mathbf{N}$ & Mean & $\begin{array}{l}\text { Standard } \\
\text { Deviation }\end{array}$ \\
\hline $\begin{array}{l}\text { SA- } \\
01\end{array}$ & $\begin{array}{l}\text { Understand the terms primary and secondary mem- } \\
\text { ory and be able to distinguish between them with re- } \\
\text { gards to cost, volatility and performance }\end{array}$ & 216 & 5.31 & 1.38 \\
\hline $\begin{array}{l}\text { SA- } \\
02\end{array}$ & $\begin{array}{l}\text { Understand the differences between SRAM, DRAM, } \\
\text { and SDRAM memory chip technologies }\end{array}$ & 216 & 4.86 & 1.48 \\
\hline $\begin{array}{l}\text { SA- } \\
03\end{array}$ & $\begin{array}{l}\text { Understand the basic design of hard drive technology } \\
\text { and be able to interpret disk performance statistics } \\
\text { such as average seek time and transfer rates }\end{array}$ & 215 & 5.04 & 1.42 \\
\hline $\begin{array}{l}\text { SA- } \\
04\end{array}$ & $\begin{array}{l}\text { Understand the low-level formatting of magnetic disk } \\
\text { drives }\end{array}$ & 216 & 4.47 & 1.67 \\
\hline $\begin{array}{l}\text { SA- } \\
05\end{array}$ & $\begin{array}{l}\text { Understand the fundamental functions of memory } \\
\text { (and other device) controllers and be able to distin- } \\
\text { guish between logical and physical memory address- } \\
\text { ing }\end{array}$ & 216 & 4.97 & 1.49 \\
\hline $\begin{array}{l}\text { SA- } \\
06\end{array}$ & $\begin{array}{l}\text { Understand the differences between RAID 0, RAID 1, } \\
\text { and RAID } 5 \text { disk clustering technologies with regards } \\
\text { to cost, reliability and performance }\end{array}$ & 216 & 5.37 & 1.56 \\
\hline $\begin{array}{l}\text { SA- } \\
07\end{array}$ & $\begin{array}{l}\text { Understand the fundamental operation of memory } \\
\text { caches and the implications of cache designs with } \\
\text { regards to application performance }\end{array}$ & 216 & 5.05 & 1.30 \\
\hline $\begin{array}{l}\text { SA- } \\
08\end{array}$ & $\begin{array}{l}\text { Understand virtual memory, or memory swap files, } \\
\text { and the implications of using virtual memory with re- } \\
\text { gards to application performance }\end{array}$ & 216 & 5.49 & 1.34 \\
\hline
\end{tabular}

\begin{tabular}{|c|c|c|c|c|}
\hline \multicolumn{5}{|c|}{ Motherboard and Bus Architectures (MA) } \\
\hline $\begin{array}{c}\text { Item } \\
\#\end{array}$ & Item & $\mathbf{N}$ & Mean & $\begin{array}{l}\text { Standard } \\
\text { Deviation }\end{array}$ \\
\hline $\begin{array}{l}\text { MA- } \\
01\end{array}$ & $\begin{array}{l}\text { Be able to identify major components on a typical computer } \\
\text { system motherboard (processor, memory and expansion } \\
\text { card slots, } 1 / O \text { ports, and device controllers) }\end{array}$ & 214 & 5.51 & 1.46 \\
\hline $\begin{array}{l}\text { MA- } \\
02\end{array}$ & $\begin{array}{l}\text { Ability to analyze and compare block diagrams of system } \\
\text { motherboards and associated chipsets }\end{array}$ & 214 & 4.15 & 1.60 \\
\hline $\begin{array}{l}\text { MA- } \\
03\end{array}$ & $\begin{array}{l}\text { Understand function of basic system chipsets used in de- } \\
\text { sign of motherboards }\end{array}$ & 212 & 4.32 & 1.64 \\
\hline $\begin{array}{l}\text { MA- } \\
04\end{array}$ & $\begin{array}{l}\text { Understand the differences between serial and parallel bus } \\
\text { architectures and be able to distinguish between PCl and } \\
\text { USB buses. }\end{array}$ & 214 & 5.02 & 1.61 \\
\hline $\begin{array}{l}\text { MA- } \\
05\end{array}$ & $\begin{array}{l}\text { Understand the differences between centralized and decen- } \\
\text { tralized bus arbitration and be able to provide examples of } \\
\text { each }\end{array}$ & 211 & 4.23 & 1.57 \\
\hline $\begin{array}{l}\text { MA- } \\
06\end{array}$ & $\begin{array}{l}\text { Understand the logic behind using multiple bus designs in } \\
\text { modern computer systems }\end{array}$ & 214 & 4.45 & 1.57 \\
\hline $\begin{array}{l}\text { MA- } \\
07\end{array}$ & $\begin{array}{l}\text { Understand I/O interrupt processing and its impact on sys- } \\
\text { tem performance }\end{array}$ & 214 & 4.93 & 1.54 \\
\hline $\begin{array}{l}\text { MA- } \\
08\end{array}$ & $\begin{array}{l}\text { Understand the use of buffering to reduce number of inter- } \\
\text { rupts and improve system performance }\end{array}$ & 212 & 4.94 & 1.48 \\
\hline
\end{tabular}




\begin{tabular}{|l|l|c|c|r|}
\hline \multicolumn{5}{|l|}{ System Administration and Security (SS) } \\
\hline $\begin{array}{l}\text { Item } \\
\text { \# }\end{array}$ & Item & Mean & $\begin{array}{l}\text { Standard } \\
\text { Deviation }\end{array}$ \\
\hline $\begin{array}{l}\text { SS- } \\
\mathbf{0 1}\end{array}$ & $\begin{array}{l}\text { Understand the basic functions of a systems adminis- } \\
\text { trator with regards to maintaining systems reliability, } \\
\text { security and performance }\end{array}$ & 215 & 6.35 & 0.83 \\
\hline $\begin{array}{l}\text { SS- } \\
\mathbf{0 2}\end{array}$ & $\begin{array}{l}\text { Understand the function and use of basic system } \\
\text { monitoring and diagnostic tools available to support } \\
\text { systems administration functions }\end{array}$ & 215 & 6.08 & 0.94 \\
\hline $\begin{array}{l}\text { SS- } \\
\mathbf{0 3}\end{array}$ & $\begin{array}{l}\text { Understand the use and limitations of common sys- } \\
\text { tem benchmarks tools and measures }\end{array}$ & 216 & 5.66 & 1.07 \\
\hline $\begin{array}{l}\text { SS- } \\
\mathbf{0 4}\end{array}$ & $\begin{array}{l}\text { Understand basic concepts of information assurance: } \\
\text { physical security, data integrity, data confidentiality, } \\
\text { and data accessibility }\end{array}$ & 216 & 6.52 & 0.80 \\
\hline $\begin{array}{l}\text { SS- } \\
\mathbf{0 5}\end{array}$ & $\begin{array}{l}\text { Understand system risk in terms of intentional and } \\
\text { unintentional risk factors }\end{array}$ & 216 & 6.25 & 1.00 \\
\hline $\begin{array}{l}\text { SS- } \\
\mathbf{0 6}\end{array}$ & $\begin{array}{l}\text { Understand common malicious threats: worm, virus, } \\
\text { Trojan horse, backdoor, and social engineering }\end{array}$ & 216 & 6.38 & 0.89 \\
\hline $\begin{array}{l}\text { SS- } \\
\mathbf{0 7}\end{array}$ & $\begin{array}{l}\text { Understand the importance of establishing security } \\
\text { policies and the necessity of user training }\end{array}$ & 216 & 6.52 & 0.82 \\
\hline $\begin{array}{l}\text { SS- } \\
\mathbf{0 8}\end{array}$ & $\begin{array}{l}\text { Understand basic user authentication and common } \\
\text { vulnerabilities associated with user passwords }\end{array}$ & 214 & 6.43 & 0.83 \\
\hline $\begin{array}{l}\text { SS- } \\
\mathbf{0 9}\end{array}$ & $\begin{array}{l}\text { Understand and be able to compare the primary func- } \\
\text { tions and limitations of firewalls and intrusion detec- } \\
\text { tion systems }\end{array}$ & 216 & 6.22 & 0.92 \\
\hline $\begin{array}{l}\text { SS- } \\
\mathbf{1 0}\end{array}$ & $\begin{array}{l}\text { Understand the basic purpose and use of encryption } \\
\text { and how public key encryption systems work }\end{array}$ & 215 & 6.05 & 0.92 \\
\hline $\begin{array}{l}\text { SS- } \\
\mathbf{1 1}\end{array}$ & $\begin{array}{l}\text { Understand the fundamental requirements for, and } \\
\text { aspects of, continuity of operations planning and sys- } \\
\text { tem / data backup techniques and capabilities }\end{array}$ & 213 & 6.39 & 0.83 \\
\hline
\end{tabular}


Appendix B

\begin{tabular}{|c|c|c|c|c|}
\hline \multicolumn{5}{|c|}{ Developers } \\
\hline Full Data & Academic & $\begin{array}{c}\text { Academic } \\
\text { \& Practi- } \\
\text { tioner }\end{array}$ & $\begin{array}{c}\text { Practitioner } \\
\text { Manager }\end{array}$ & $\begin{array}{c}\text { Practitioner } \\
\text { Technical }\end{array}$ \\
\hline Approximate $\mathrm{N}$ & 19 & 8 & 10 & 14 \\
\hline Systems Orientation & 5.69 & 5.84 & 5.84 & 5.87 \\
\hline Systems Architect \& OS & 4.05 & 3.96 & 4.95 & 5.14 \\
\hline Data Representation & 3.91 & 3.86 & 3.91 & 4.66 \\
\hline Processor Architecture & 3.85 & 2.94 & 3.89 & 4.10 \\
\hline Storage Architecture & 4.50 & 3.68 & 5.51 & 4.68 \\
\hline Motherboard/Bus Architecture & 3.89 & 2.95 & 4.71 & 4.40 \\
\hline Sys Admin \& Security & 6.07 & 6.13 & 6.41 & 6.11 \\
\hline
\end{tabular}

\begin{tabular}{|l|c|c|c|c|}
\hline \multicolumn{5}{|c|}{ Infrastructure } \\
\hline \multicolumn{1}{|c|}{ Full Data } & Academic & $\begin{array}{c}\text { Academic } \\
\text { \& Practi- } \\
\text { tioner }\end{array}$ & $\begin{array}{c}\text { Practitioner } \\
\text { Manager }\end{array}$ & $\begin{array}{c}\text { Practitioner } \\
\text { Technical }\end{array}$ \\
\hline Approximate N & 2 & 7 & 11 & 41 \\
\hline Systems Orientation & 5.93 & 5.57 & 5.71 & 5.81 \\
\hline Systems Architect \& OS & 5.14 & 4.94 & 5.25 & 5.41 \\
\hline Data Representation & 5.21 & 4.61 & 4.42 & 4.81 \\
\hline Processor Architecture & 5.25 & 4.66 & 4.69 & 4.88 \\
\hline Storage Architecture & 5.44 & 5.43 & 5.43 & 5.63 \\
\hline Motherboard/Bus Architecture & 5.00 & 4.79 & 4.98 & 5.22 \\
\hline Sys Admin \& Security & 6.23 & 6.40 & 6.43 & 6.42 \\
\hline
\end{tabular}

\begin{tabular}{|l|c|c|c|c|}
\hline \multicolumn{5}{|c|}{ Delta Infrastructure - Developers } \\
\hline Delta & Academic & $\begin{array}{c}\text { Academic } \\
\text { \& Practi- } \\
\text { tioner }\end{array}$ & $\begin{array}{c}\text { Practitioner } \\
\text { Manager }\end{array}$ & $\begin{array}{c}\text { Practitioner } \\
\text { Technical }\end{array}$ \\
\hline Approximate N & 2 & 7 & 11 & 41 \\
\hline Systems Orientation & 0.24 & -0.27 & -0.13 & -0.06 \\
\hline Systems Architect \& OS & 1.09 & 0.98 & 0.30 & 0.27 \\
\hline Data Representation & 1.30 & 0.75 & 0.51 & 0.15 \\
\hline Processor Architecture & 1.40 & 1.72 & 0.80 & 0.78 \\
\hline Storage Architecture & 0.94 & 1.75 & -0.08 & 0.95 \\
\hline Motherboard/Bus Architecture & 1.11 & 1.84 & 0.27 & 0.82 \\
\hline Sys Admin \& Security & 0.16 & 0.27 & 0.02 & 0.31 \\
\hline
\end{tabular}




\section{Biographies}

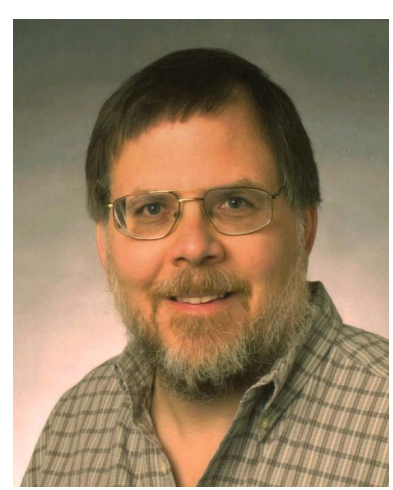

John C. Beachboard joined the Computer Information Systems faculty at Idaho State University in 2001. He completed the Ph.D. in Information Transfer and the M.S. in Information Resources Management at the School of Information Studies, Syracuse University. He holds an M.S. in Business Administration from Boston University and a B.S. in Public Administration from the University of Arizona. Dr. Beachboard has taught graduate courses in research methods, project management, and IT use in business, and undergraduate courses in IT management and systems architectures. He has held staff and management positions developing, implementing and operating information and telecommunications systems for the Department of Defense. He is keenly interested in the development, application and effectiveness of information technology management policies in the private and public sectors.

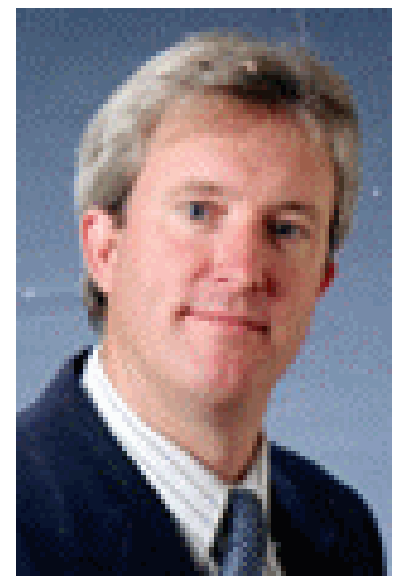

Kevin R. Parker is a Professor of Computer Information Systems at Idaho State University. He has taught classes in both computer science and information systems over the course of his thirteen years in academia. Dr. Parker's research interests include e-commerce marketing, competitive intelligence, information filtering, knowledge management, the Semantic Web, and extreme programming. He has published several papers in these areas including publications in the International Journal of Internet and Enterprise Management, Journal of Information Systems Education, Journal of Issues in Informing Science and Information Technology, European Journal of Marketing, and Marketing Intelligence and Planning as well as refereed chapters in researchbased books. Dr. Parker's teaching interests include web development technologies, programming languages, data structures, and database management systems. Dr. Parker holds an MS in Computer Science and a Ph.D. in Management Information Systems from Texas Tech University. 